\title{
Cod Year-class Variations and Abundance of Other Commercial Fish in NAFO Divisions 3NO
}

\author{
J. Paz \\ Instituto Español de Oceanografia, Centro Costero de Vigo \\ Cabo Estay - Canido, Apartado 1.552, 36080, Vigo, Spain \\ and \\ M. G. Larrañeta \\ Instituto de Investigaciones Marinas, Eduardo Cabello 6, \\ 36208 Vigo, Spain
}

\begin{abstract}
Possible biological relationships of cod (Gadus morhua) with other important commercial fishes are explored. Cod year-class variations are compared with variations of yellowtail flounder and American plaice spawning biomass, mackerel age 1+ group abundance, and redfish densities. The adult fish biomass of these species are considered as an index of their egg and larval abundances. Possible competitive and predator-prey relationships between the 0-age groups and young individuals of cod and these species are examined through correlation analyses. No significant relationships between cod and redfish and yellowtail flounder were found. It seems that mackerel is a predator on cod larvae. A positive high correlation between spawning American plaice biomass and cod year-class strength was found. High American plaice spawning biomass may promote high cod recruitment through a predator-prey interaction. Alternatively, both species may respond similarly to an environmental signal.
\end{abstract}

\section{Introduction}

Physical environmental factors, especially longterm changes, govern the biotic fluctuations of ecosystems, but how these fluctuations affect individual species is still not clear. It can be expected that the immediate factors in the dynamics of a species are essentially biological through trophic interactions, and that physical factors are secondary. Perhaps multispecies models have the defect of limiting themselves to trophic relationships, ignoring the fact that these depend, at least in the long-term, on physical environmental factors.

In this context, cod (Gadus morhua) year-class variations were compared with variations of adult biomass of yellowtail flounder (Limanda ferruginea) and American plaice (Hippoglossoides platessoides), mackerel (Scomber scombrus) age 1+ group abundances, and redfish (Sebastes sp.) densities to examine potential biotic interactions at different life history stages. Adults of these species, except mackerel, are not considered to be predators of eggs and larvae of cod. The egg and larval abundance of these is considered to be directly related to their adult biomass. However, there may be competition and predator-prey relationships between the 0 -age groups and young individuals of cod and American plaice, yellowtail flounder and redfish. It was expected that the sign of correlations will indicate the possible nature of those relationships.

\section{Materials and Methods}

The possibility of trophic relationships between 0 -age groups and juveniles of cod and other species was explored relating cod year-class size to the biomass of other species, from 1 to 3 years before (negative lag) and after (positive lag) the year of the cod year-class. Using regression analysis, the relationships were explored for the cod year-class in relation to spawning biomass which gave rise to it, and to the cod spawning biomass lagged from 1 to 3 years before or after. The cod year-class size was measured at time of recruitment according to a virtual population analysis in the usual practice, at three years of age $\left(\mathrm{N}_{3}\right)$. The cod recruitment $\left(\mathrm{N}_{3}\right)$ and spawning biomass $\left(\mathrm{B}_{6+}\right)$ data (Table 1) were taken from Baird and Bishop (MS 1989).

Correlations coefficients were calculated between cod year-class variations and the fluctuations of other species:

a) redfish densities,

b) yellowtail flounder spawning biomass,

c) mackerel biomass,

d) American plaice spawning biomass. 
TABLE 1. Cod Div. 3NO: recruitment $\left(\mathrm{N}_{3}\right)$ and spawning biomass $\left(\mathrm{B}_{6+}\right)$. (From Baird and Bishop, MS 1989).

\begin{tabular}{|c|c|c|}
\hline Year-class & $\begin{array}{c}\text { Recruits } \\
\left(10^{3}\right)\end{array}$ & $\begin{array}{c}\text { Biomass } \\
\text { ('000 tons) }\end{array}$ \\
\hline 1956 & 5368 & - \\
\hline 1957 & 5309 & - \\
\hline 1958 & 8214 & - \\
\hline 1959 & 10776 & 8840 \\
\hline 1960 & 7825 & 7234 \\
\hline 1961 & 11238 & 8974 \\
\hline 1962 & 16252 & 8032 \\
\hline 1963 & 20999 & 8787 \\
\hline 1964 & 18324 & 11264 \\
\hline 1965 & 10050 & 12051 \\
\hline 1966 & 12785 & 10462 \\
\hline 1967 & 8032 & 9344 \\
\hline 1968 & 8442 & 8268 \\
\hline 1969 & 6211 & 8026 \\
\hline 1970 & 3502 & 8137 \\
\hline 1971 & 3654 & 8819 \\
\hline 1972 & 2283 & 7812 \\
\hline 1973 & 2714 & 7618 \\
\hline 1974 & 4536 & 5373 \\
\hline 1975 & 4258 & 1929 \\
\hline 1976 & 1807 & 1233 \\
\hline 1977 & 2078 & 1655 \\
\hline 1978 & 2921 & 1948 \\
\hline 1979 & 2306 & 2628 \\
\hline 1980 & 3549 & 5713 \\
\hline 1981 & 5079 & 8830 \\
\hline 1982 & 4716 & 9152 \\
\hline 1983 & 952 & 10004 \\
\hline 1984 & 1000 & 9556 \\
\hline 1985 & 3300 & 10305 \\
\hline 1986 & - & 11069 \\
\hline 1987 & - & 10990 \\
\hline 1988 & - & 9120 \\
\hline
\end{tabular}

The yellowtail flounder spawning biomass data were obtained from the sequential population analysis using a short-term average partial recruitment (1982-86) and a terminal F of 0.9 reported by Brodie and Walsh (MS 1987). The American plaice spawning biomasses $\left(B_{11+}\right)$ were taken from Brodie (MS 1988). The redfish abundances were taken from Power and Atkinson (MS 1987), where a multiplicative model was used to derive catch rates in NAFO Div. 3LN during 1959-86, and the values used were the mean abundances calculated from three consecutive years. Finally, the mackerel biomasses $\left(B_{1+}\right)$ were taken from Anon. (1986) which referred to the Labrador-North Carolina area. All these data are shown in Tables 2-5.

When a 0 year lag time was used, the year-class of recruitment related to the spawning biomass of the species in the same year as that of the cod year-
TABLE 2. Yellowtail flounder Div. 3LNO: spawning stock biomass $\left(\mathrm{B}_{6+}\right)$. (From tables 23 and 24 of Brodie and Walsh, MS 1987).

\begin{tabular}{lcc}
\hline Year & $\begin{array}{c}\text { Table 23 } \\
\text { (tons) }\end{array}$ & $\begin{array}{c}\text { Table } 24 \\
\text { (tons) }\end{array}$ \\
\hline 1968 & 25926 & 25926 \\
1969 & 40372 & 40372 \\
1970 & 50199 & 50199 \\
1971 & 48747 & 48747 \\
1972 & 33846 & 33846 \\
1973 & 24049 & 24049 \\
1974 & 21034 & 21034 \\
1975 & 18159 & 18159 \\
1976 & 19152 & 19152 \\
1977 & 18809 & 18809 \\
1978 & 21776 & 21776 \\
1979 & 17413 & 17412 \\
1980 & 26322 & 26322 \\
1981 & 20350 & 20337 \\
1982 & 16838 & 16642 \\
1983 & 30565 & 28894 \\
1984 & 53811 & 47448 \\
1985 & 63087 & 50550 \\
1986 & 39536 & 23722 \\
\hline
\end{tabular}

class, that is to say, three years before recruitment $\left(\mathrm{N}_{3}\right)$.

\section{Results}

Correlations between cod recruitment and its spawning biomass are shown in Table 6. The coefficients appeared to be slightly significant for 0 to +2 year lags.

Correlation coefficients between cod year-class size and redfish abundance are shown in Table 7 , none were significant. Also, none of the correlation coefficients between cod recruitment and yellowtail flounder spawning biomass (Table 8) were significant. On the other hand, correlation coefficients between cod recruitment and mackerel abundance (Table 9) were negative and slightly significant for 0 to -3 year lags, and between cod recruitment and American plaice spawning biomass they were positive and strongly significant (Table 10) with lag times of $0,+1,+2$ and +3 years. The two highest correlation coefficients for the relationship between cod year-class size and American plaice spawning biomass were for lags of 0 and +3 years. Regression analyses for these years are given in Fig. 1 and Fig. 2, respectively, and the regression coefficients for these cases were the following:

\begin{tabular}{ccc}
\hline lag & $a$ & $b$ \\
\hline 0 & -586.76 & 0.06624 \\
3 & -3352.1 & 0.13276 \\
\hline
\end{tabular}


PAZ and LARRAÑETA: Cod Year-class Variations and Abundance of Other Fish in Div. 3NO

TABLE 3. Redfish Div. 3LN: average catch rate of three years. (From figure 3 of Power and Atkinson, MS 1987)

\begin{tabular}{cc}
\hline \hline Middle year & Catch rate \\
\hline & \\
1960 & 1.15 \\
1961 & 1.21 \\
1962 & 1.28 \\
1963 & 1.25 \\
1964 & 1.04 \\
1966 & 1.11 \\
1967 & 1.08 \\
1968 & 1.06 \\
1969 & 0.89 \\
1970 & 0.90 \\
1971 & 1.01 \\
1972 & 1.04 \\
1973 & 1.06 \\
1974 & 1.15 \\
1975 & 1.18 \\
1976 & 1.13 \\
1977 & 1.02 \\
1978 & 0.92 \\
1979 & 0.98 \\
1980 & 1.11 \\
1981 & 1.25 \\
1982 & 1.33 \\
1983 & 1.33 \\
& 1.25 \\
\hline &
\end{tabular}

A multiple regression was also calculated, where $X_{1}$ was the American plaice spawning biomass with a 0 year lag, and $X_{2}$ the American plaice biomass with $a+3$ year lag. The resulting expression was $Y=-$ $1.4714+0.0392 X_{1}+0.0492 X_{2}$, and the correlation coefficient 0.911 .

\section{Discussion}

The relationship between cod recruitment and its spawning biomass (Table 6) corresponds to the complex problem of the stock-recruitment question, which is not the object of this study. These correlations were made to simply follow the same method as in the case of the other species abundance. Nevertheless, the absence of negative correlations with negative lags (cod spawning biomass before the year-class) indicated that cannibalism did not determine year-class size. Koslow et al. (1987) have found that in NAFO Div. 3NO areas the highest cod recruitments are obtained from the lowest egg densities.

There was no significant relationship between redfish and yellowtail flounder abundances, and cod year-class size. On the one hand, a negative
TABLE 4. Mackerel Labrador-North Carolina: population biomass $\left(B_{1+}\right)$. (From figure 19.1, Anon., 1986).

\begin{tabular}{lc}
\hline \hline Year & $\begin{array}{c}\text { Biomass } \\
\text { ('000 tons) }\end{array}$ \\
\hline 1963 & 275 \\
1964 & 311 \\
1965 & 323 \\
1966 & 371 \\
1967 & 623 \\
1968 & 1198 \\
1969 & 1533 \\
1970 & 1856 \\
1971 & 1868 \\
1972 & 1653 \\
1973 & 1389 \\
1974 & 1126 \\
1975 & 970 \\
1976 & 719 \\
1977 & 491 \\
1978 & 467 \\
1979 & 503 \\
1980 & 467 \\
1981 & 479 \\
1982 & 599 \\
1983 & 695 \\
1984 & 1,078 \\
\hline
\end{tabular}

TABLE 5. American plaice Div. 3LNO: spawning stock biomass $\left(\mathrm{B}_{11_{+}}\right)$. (From Brodie, MS 1988).

\begin{tabular}{lr}
\hline \hline Year & $\begin{array}{c}\text { Biomass } \\
\text { ('000 tons) }\end{array}$ \\
\hline 1965 & 138197 \\
1966 & 158756 \\
1967 & 157325 \\
1968 & 138837 \\
1969 & 120238 \\
1970 & 94378 \\
1971 & 81403 \\
1972 & 62129 \\
1973 & 52619 \\
1974 & 50889 \\
1975 & 45906 \\
1976 & 39864 \\
1977 & 45515 \\
1978 & 48818 \\
1979 & 60846 \\
1980 & 67125 \\
1981 & 53278 \\
1982 & 46852 \\
1983 & 42294 \\
1984 & 46090 \\
1985 & 56357 \\
1986 & 43383 \\
\hline
\end{tabular}


TABLE 6. Correlations between cod year-class sizes $\left(\mathrm{N}_{3}\right)$ and cod spawning stock biomass.

\begin{tabular}{lrrrrrrr}
\hline \hline Lag & -3 & -2 & -1 & 0 & 1 & 2 & 3 \\
\hline $\mathrm{n}=$ & 24 & 25 & 26 & 27 & 28 & 29 & 30 \\
$\mathrm{r}=$ & 0.296 & 0.344 & 0.393 & 0.441 & 0.463 & 0.452 & 0.389 \\
$\mathrm{p}=$ & 0.162 & 0.930 & 0.046 & 0.020 & 0.012 & 0.013 & 0.033 \\
\hline
\end{tabular}

TABLE 7. Correlations between cod year-class sizes $\left(\mathrm{N}_{3}\right)$ and redfish catch rates.

\begin{tabular}{lrrrrrrr}
\hline \hline Lag & -3 & -2 & -1 & 0 & 1 & 2 & 3 \\
\hline $\mathrm{n}=$ & 23 & 24 & 24 & 24 & 24 & 24 & 24 \\
$\mathrm{r}=$ & 0.219 & 0.229 & 0.303 & 0.179 & $2 \mathrm{E}-4$ & -0.199 & -0.308 \\
$\mathrm{p}=$ & 0.319 & 0.284 & 0.152 & 0.406 & 0.999 & 0.355 & 0.145 \\
\hline
\end{tabular}

TABLE 8. Correlations between cod year-class sizes $\left(\mathrm{N}_{3}\right)$ and yellowtail flounder spawning stock biomass $\left(\mathrm{B}_{6+}\right)$.

\begin{tabular}{lrrrrrrr}
\hline \hline Lag & -3 & -2 & -1 & 0 & 1 & 2 & 3 \\
\hline $\mathrm{n}=$ & 15 & 16 & 17 & 18 & 19 & 20 & 20 \\
$\mathrm{r}=$ & 0.099 & 0.120 & 0.028 & 0.115 & -0.087 & 0.148 & 0.434 \\
$\mathrm{p}=$ & 0.740 & 0.663 & 0.915 & 0.656 & 0.726 & 0.552 & 0.063 \\
\hline
\end{tabular}

TABLE 9. Correlations between cod year-class sizes $\left(\mathrm{N}_{3}\right)$ and mackerel stock biomass.

\begin{tabular}{lrrrrrrr}
\hline \hline Lag & -3 & -2 & -1 & 0 & 1 & 2 & 3 \\
\hline $\mathrm{n}=$ & 20 & 21 & 22 & 22 & 22 & 22 & 22 \\
$\mathrm{r}=$ & -0.408 & -0.444 & -0.439 & -0.421 & -0.373 & -0.246 & -0.074 \\
$\mathrm{p}=$ & 0.074 & 0.043 & 0.040 & 0.050 & 0.087 & 0.275 & 0.748 \\
\hline
\end{tabular}

TABLE 10. Correlations between cod year-class sizes $\left(\mathrm{N}_{3}\right)$ and American plaice spawning stock biomass.

\begin{tabular}{lrrrrrrr}
\hline \hline Lag & -3 & -2 & -1 & 0 & 1 & 2 & 3 \\
\hline $\mathrm{n}=$ & 18 & 19 & 20 & 21 & 22 & 22 & 22 \\
$\mathrm{r}=$ & 0.470 & 0.693 & 0.774 & 0.876 & 0.830 & 0.863 & 0.940 \\
$\mathrm{p}=$ & 0.480 & $<0.001$ & $<0.001$ & $<0.001$ & $<0.001$ & $<0.001$ & $<0.001$ \\
\hline
\end{tabular}

correlation between mackerel and cod abundance suggested that mackerel preyed on cod. It is known that adult mackerel prey on planktonic stages of other fishes. These correlations extended also to +1 and +2 year lags (Table 9 ), but predation by mackerel on 1 and 2 year age groups of cod seemed very unlikely because of the large size of the prey. It is more reasonable to think that mackerel abundance will remain similar during the following 2 years to that of the 0 lag year. According to Koslow et al. (1987), several authors have noted the influence of mackerel abundance on Gadidae and herring recruitment in areas from Georges Bank to the Gulf of Saint Lawrence, and these had been attributed to predation by mackerel. In contrast, Báez and Larrañeta (MS 1987) have found that silver hake (Merluccius bilinearis) year-class sizes on the Scotian Shelf are positively correlated with mackerel biomasses, suggesting predation on mackerel 0 -age group by silver hake 0 -age group. 


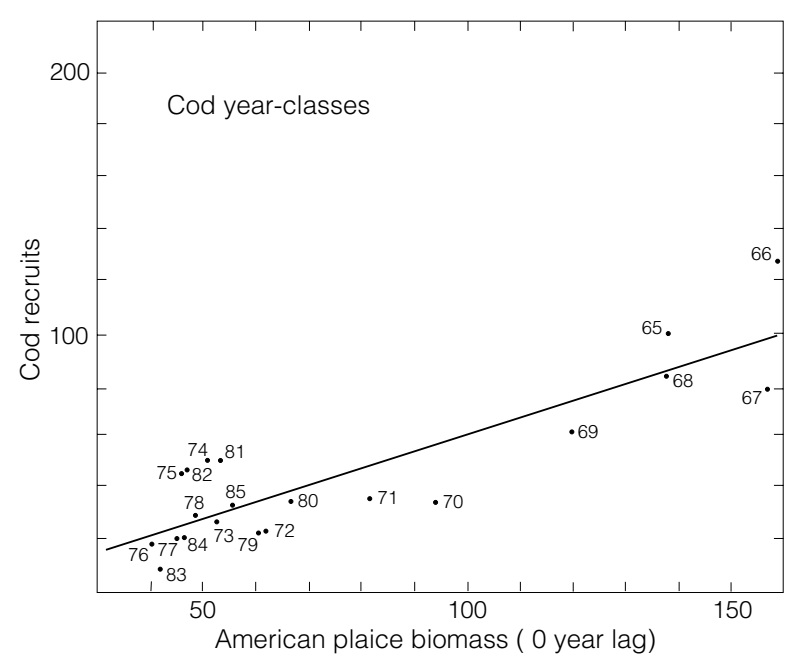

Fig. 1. Relationship between American plaice spawning biomass (000 tons) with a lag of 0 years from cod year-class and cod recruitment $\left(\mathrm{N} \times 10^{-5}\right)$.

The most striking results were obtained with the American plaice (Table 10). The positive and high correlations suggest a great predation of 0-group cod on American plaice spawn (eggs and larvae) and the resulting 0 -group fish, which occur throughout the cod pre-recruitment period. Significant correlations with lags of -1 and -2 years may be because American plaice spawning biomasses had a previous abundance similar to that corresponding to the year with a lag of 0 years. It was previously shown (Larrañeta, 1986), that variations of Div. 3NO cod and American plaice year-class sizes are inversely related, which is consistent with the present results. In fact, if 0-group cod prey actively on 0group American plaice, or both are strong competitors, they would exclude the simultaneous production of the highest year-classes possible for each species. Notwithstanding the very high significant levels obtained in the statistical tests, we realize that too many of the data points lie in the lower left quadrant of Fig. 1 and 2, and for this reason it will be important to examine this relationship in a future period when American plaice biomass again increases.

Literature supports the view that American plaice can be an important prey of cod during the 0-age group and pre-recruitment stages. Marak (1960) studied the feeding habits of haddock and cod postlarvae (19-23 mm) on Georges Bank and found that $33 \%$ of the stomach contents were fish eggs. In Iceland waters Pälsson (1983) cited the predation of cod on American plaice. Here the stomach content by weight in cod ranging from 15 to 19 and 25 to $29 \mathrm{~cm}$ comprised 16 and $9 \%$, respectively of American plaice. Similarly, Daan (1973) cites that

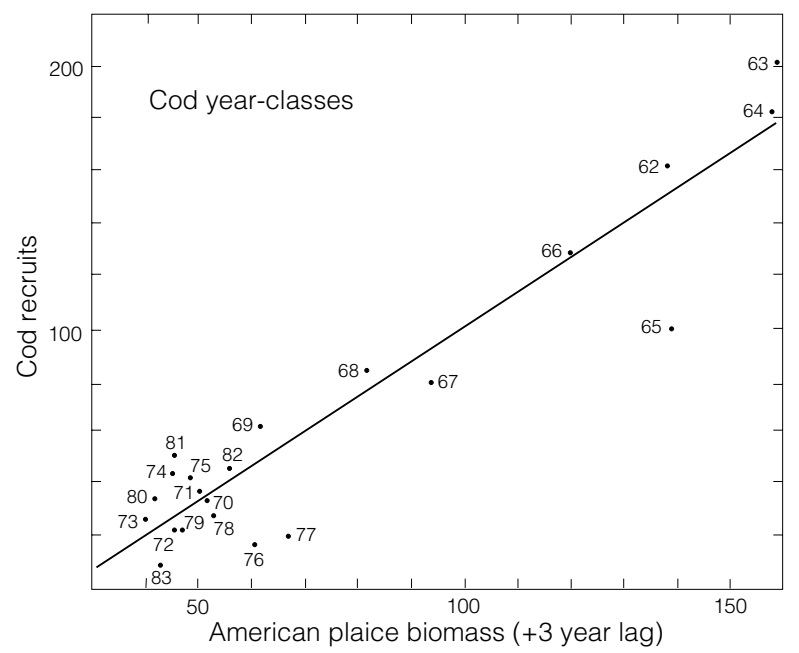

Fig. 2. Relationship between American plaice spawning biomass (000 tons) with a lag of +3 years from cod year-class and cod recruitment $\left(\mathrm{N} \times 10^{-5}\right)$.

the food of cod 10-19 cm long in the North Sea consisted of $85 \%$ of the Pleuronectidae; Limanda limanda is of the same family. Hawkins (1985) also indicates that Pleuronectidae are food of young cod (13-43 cm). These studies support the idea of strong predation by cod on 0-group American plaice and also an active predation on the juveniles.

The data available on cod and American plaice distribution in Div. 3NO favour this idea. The northern and southeastern slopes of the Grand Bank support the largest American plaice concentration in the Northwest Atlantic (Pitt, 1966). According to Wells et al. (MS 1988), cod and American plaice have similar distributions on the Grand Bank, although cod does not tolerate temperatures less than $-1^{\circ} \mathrm{C}$ that well. Yellowtail flounder is distributed in shallower zones and warmer waters, with temperatures always above $1^{\circ} \mathrm{C}$. On the southern Grand Bank area, separation between American plaice pre-recruits and adults is not observed (Walsh, 1982; Walsh and Brodie, MS 1988) as it is in European waters, because the oceanographic conditions tend to retain the eggs and larvae near the spawning area (Nevinsky and Serebryakov, 1973). The metamorphosed juveniles ( $>20 \mathrm{~mm}$ ) occupy the same areas as the spawning adults. American plaice larvae concentrate almost exclusively on the southeastern area of Grand Bank, in waters colder than $1^{\circ} \mathrm{C}$. One other distinguishing characteristic of yellowtail flounder is that they are distributed in waters warmer than $1^{\circ} \mathrm{C}$. According to Kenneth et al. (1988), American plaice appear not to migrate vertically during either the larval or pelagic juvenile phases, and are always collected below the pycnocline at an average depth of about $30 \mathrm{~m}$. The 
poor dispersion of American plaice could make it more vulnerable to predation.

The correlation coefficient between American plaice spawning biomass and cod recruitment was greater for a lag of +3 years than for lags of +1 or +2 years, and were even higher than for a lag of 0 years. We have interpreted the high correlation when there was a lag of 0 years, as a predation by individuals of the cod 0-group on those of the American plaice 0-group, but it seems unacceptable that 3-year-old cod prey on American plaice 0-group. A better hypothesis to explain the very high correlation with a lag of +3 years could be that adult cod is attracted by an abundant American plaice spawning population, reducing cannibalism of adult cod on 0-3 year age groups. According to unpublished data of J. Paz, the cod of $4+$ age-groups cannibalize the 1-3 year age groups. In this case, prerecruit cod would have two critical periods: the first one owing to feeding conditions, the second one owing to cannibalism.

These considerations suggest that the presence of a high American plaice spawning biomass promotes high cod recruitment. Alternatively, both species may respond similarly to an environmental signal. These analyses are exploratory and further research will be necessary to study the mechanisms underlying these correlations.

\section{Acknowledgements}

We are indebted to T. Wyatt for critically reviewing this manuscript. The authors thank Carmen Alonso for helpful comments of the English text.

\section{References}

ANON. 1986. Status of the fishery resources off the Northeastern United States for 1986. NOAA Tech. Mem., NMFS/NEC-43, $130 \mathrm{p}$.

BÁEZ, M., and M. G. LARRAÑETA. MS 1987. Fishery ecology of silver hake in Divisions 4VWX. NAFO SCR Doc., No. 11, Serial No. N1280, 19 p.

BAIRD, J. W., and C. A. BISHOP. MS 1989. The assessment of the cod stock in NAFO Div. 3NO. NAFO SCR Doc., No. 35, Serial No. N1611, 61 p.

BRODIE, W. B. MS 1988. An assessment of the American plaice stock in Divisions 3LNO. NAFO SCR Doc., No. 37, Serial No. N1477, $51 \mathrm{p}$.

BRODIE, W. B., and S. J. WALSH. MS 1987. An assessment of the yellowtail flounder stock in Div. 3LNO. NAFO SCR Doc., No. 44, Serial No. N1331, 24 p.

DAAN, N. 1973. A quantitative analysis of the food intake of North Sea cod, Gadus morhua. Neth. J. Sea Res., 6(4): 479-517.

HAWKINS, A. D., N. M. SOOFIANI, and G. W. SMITH. 1985. Growth and feeding of juvenile cod. ICES J. Cons., 42(1): 11-32.

KENNETH, T. F., J. E. CARSCADDEN, and W. C. LEGGETT. 1988. Comparative analysis of factors underlying of capelin and flatfish larvae on the southern Grand Banks. ICES, Early life history Symposium, Paper No. 107, 11 p. + 10 fig.

KOSLOW, J. A., K. R. THOMPSON, and W. SILVERT. 1987. Recruitment to Northwest Atlantic cod (Gadus morhua) and haddock (Melanogrammus aeglefinus) stocks: influence of stock size and climate. Can. J. Fish. Aquat. Sci., 44: 26-39.

LARRAÑETA, M. G. 1986. Dynamics of yellowtail flounder and American plaice populations in the Grand Bank. NAFO Sci. Coun. Studies, 10: 35-45.

MARAK, R. R. 1960. Food habits of larval cod, haddock and capelin in the Gulf of Maine and Georges Bank area. ICES J. Cons., 25(1): 147-157.

NEVINSKY, M. M., and V. P. SEREBRYAKOV. 1973. American plaice, Hippoglossoides platessoides platessoides Fabr., spawning in the Northwest Atlantic area. ICNAF Res. Bull., 10: 23-36.

PÄLSSON, O. K. 1983. The feeding habits of demersal fish species in Icelandic waters. Rit Fiskideild., vol. VII(1): $60 \mathrm{p}$.

PITT, T. K. 1966. Sexual maturity and spawning of the American plaice, Hippoglossoides platessoides (Fabricius), from Newfoundland and Grand Bank areas. J. Fish. Res. Board Can., 23: 651-672.

POWER, D., and D. B. ATKINSON. MS 1987. Redfish in NAFO Divisions 3LN. NAFO SCR Doc., No. 58, Serial No. N1347, 18 p.

WALSH, S. J. 1982. Distribution and abundance of prerecruit and commercial-sized American plaice on the Grand Bank. J. Northw. Atl. Fish. Sci., 3(2): 149-157.

WALSH, S. J., and W. B. BRODIE. MS 1988. American plaice distribution on the Nose and Tail of the Grand Bank. NAFO SCR Doc., No. 28, Serial No. N1464, 12 p.

WELLS, R., W. B. BRODIE, C. A. BISHOP, and J. W. BAIRD. MS 1988. Distribution and abundance of three fish species on the Grand Bank in relation to depth and temperature of the water. NAFO SCR Doc., No. 94, Serial No. N1546, 